\title{
COMPOSITION, STRUCTURE AND DIVERSITY OF COASTAL VEGETATION IN THE NORTHEASTERN of CozUmel, MeXico
}

\section{COMPOSICIÓN, ESTRUCTURA Y DIVERSIDAD DE LA VEGETACIÓN COSTERA DEL NORESTE DE COZUMEL, MÉXICO}

\author{
Alejandro Collantes-Chávez-Costa ${ }^{1, *}$, Eduardo Alanís-Rodríguez ${ }^{2}$, Oscar Yam-UicaB ${ }^{1}$, Cruz López- \\ CONTRERAS ${ }^{1}$, TANIA SARMIENTO-MUÑOZ ${ }^{3}$, AND JOSÉ LUIS TAPIA-MUÑOZ ${ }^{4}$
}

\author{
${ }^{1}$ División de Desarrollo Sustentable, Universidad de Quintana Roo, México. \\ ${ }^{2}$ Facultad de Ciencias Forestales, Universidad Autónoma de Nuevo León, México. \\ ${ }^{3}$ Gestión Estratégica y Manejo Ambiental S.C., México. \\ ${ }^{4}$ Herbario CICY, Centro de Investigación Científica de Yucatán A.C., México \\ *Corresponding author: collants@uqroo.edu.mx
}

\begin{abstract}
Background: Cozumel island, Mexico has one of the best preserved and threatened coastal vegetation in the Mexican Caribbean. Increasing the ecological knowledge about these communities can help to establish conservation priorities.

Question: How are the structure and composition of well-preserved coastal vegetation communities in the Island of Cozumel?

Study site and dates: The study was conducted in the northeastern coast of the island of Cozumel, at the Municipality of Cozumel, Quintana Roo, Mexico, from July 2014 to November 2014.

Methods: Five interception lines of $80 \mathrm{~m}$ were randomly established along environmental gradient, perpendicular to the coastal line, in each three different environments: rocky beaches, sandy beaches, and coastal dunes. Species richness, diversity, and importance value index of the species in the community were computed, and floristic composition recorded.

Results: We recorded 23 families, 35 genera and 37 species. The most representative families are Poaceae with four species, Rubiaceae and Asteraceae with three species each; Sideroxylon and Euphorbia were the richest genera, with two species each. The three coastal environments presented no statistical differences in its relative density, coverage and diversity, but differed in species composition and richness (higher in rocky beaches and coastal dunes).

Conclusions: Two dissimilar coastal plant communities can be recognized into the halophilous vegetation type, which are established in sandy and rocky environments respectively. The floristic composition and the species association of the rocky beaches reveal the relationship between the Island of Cozumel coastal vegetation and plant communities in other Caribbean islands.
\end{abstract}

Keywords: Caribbean, coastal dunes vegetation, phytosociology, plant ecology, rocky beaches vegetation, sandy beaches vegetation.

\section{Resumen}

Antecedentes: Cozumel tiene una de las vegetaciones costeras más conservadas y amenazadas en el Caribe mexicano. El incremento del conocimiento de estas comunidades puede ayudar a establecer prioridades de conservación.

Pregunta: ¿Cómo es la estructura y composición de la vegetación costera en la isla de Cozumel?

Lugar y fechas del estudio: El estudio se realizó en la costa noreste de la isla de Cozumel, Municipio de Cozumel, Quintana Roo, México, desde julio de 2014 hasta noviembre de 2014.

Método: Se establecieron aleatoriamente cinco líneas de intercepción de $80 \mathrm{~m}$ en un gradiente ambiental, perpendicular a la costa, en tres entornos diferentes: playa rocosa, playa arenosa y duna costera. Se calculó la riqueza, la diversidad y el índice de valor de importancia de las especies, y se registró la composición florística.

Resultados: Registramos 23 familias, 35 géneros y 37 especies. Las familias más representativas son Poaceae con cuatro especies, Rubiaceae y Asteraceae con tres cada una; Sideroxylon y Euphorbia fueron los géneros con mayor riqueza, dos especies cada uno. Los tres ambientes no presentaron diferencias en su densidad relativa, cobertura y diversidad, pero sí en la composición y riqueza (mayor en playa rocosa y duna costera).

Conclusiones: Se reconocen dos comunidades de vegetales de tipo de vegetación halófila, las de ambientes arenosos y rocoso respectivamente. La composición florística y la asociación de especies de la playa rocosa revelan la relación entre la vegetación costera de Cozumel y las comunidades de plantas en otras islas del Caribe.

Palabras clave: Caribe, ecología vegetal, fitosociología, vegetación de duna costera, vegetación de playa arenosa, vegetación de playa rocosa.

This is an open access article distributed under the terms of the Creative Commons Attribution License CCBY-NC (4.0) international. https://creativecommons.org/licences/by-nc/4.0/ 
Coastal vegetation, specially these of the coastal dunes, plays a relevant ecological role by providing important environmental support services. This plant community, located in the transition zone between the marine and terrestrial environments; it is an important source of food, refuges and habitats for diverse species of animals and plants, and significantly favors the presence and maintenance of biodiversity (Martínez \& Moreno-Casasola 1993, Flores \& Espejel 1994, Moreno-Casasola 2004, Acevedo-Rodríguez \& Strong 2008, Carboni et al. 2009). Likewise, it offers significant regulatory services, by contributing to soil formation (Wolfe \& Nickling 1993) and the control of erosion and floods, since the plant dune communities act as natural barriers against the pounding of winds and tides caused by cyclonic events characteristic of the tropical zone (Miller et al. 2010).

Despite the importance of this coastal plant community of the tropical and subtropical regions, it is one of the most threatened and vulnerable natural system in Mexico and the world (Martínez \& Moreno-Casasola 1993, Moreno-Casasola et al. 1998, Herrera-Silveira et al. 2005, Isla 2013). Seingier et al. (2009) report for Mexico the loss of approximately $14 \%$ of the coastal dunes of the country, with the Mexican Caribbean region having the greatest loss of coastal dunes vegetation. Due to the threat to which these natural systems are exposed, it is necessary to take actions to protect them. Improving scientific knowledge of these natural coastal communities can help to fill in conservation gaps and promote the development of protective strategies (Jiménez-Orocio et al. 2015).

In general, the coastal vegetation of Mexico is classified by Rzedowski (2006) within other types of vegetation. In this group, it refers to halophilous vegetation. In this type of vegetation, plant associations typical of sandy beaches and coastal dunes vegetation are described, both in the Atlantic and Pacific coasts, as well as in the coasts of Baja California, and other associations typical of the beaches of brackish lagoons. Some of the representative species mentioned by Rzedowski (2006) are Cakile lanceolata, Canavalia rosea, Ipomoea pes-caprae in the herbaceous stratum; and Coccoloba uvifera, Suriana maritima, Thournefortia gnaphalodes and Bonellia macrocarpa in the shrubby stratum.

On the other hand, Miranda \& Hernández (1963) refer to halophilic groupings, such as vegetation that grows near the coast, but which predominates in saline bottoms of closed basins of arid and sub-arid zones, with different degrees of flooding. In addition to the grouping of halophiles, Miranda \& Hernández (1963) cite coastal dunes vegetation, characteristic of coastal areas with sandy soils of different degrees of mobility. As representative species of this type of vegetation they mention I. pes-caprae and C. uvifera.

The coastal vegetation of the Yucatan Peninsula is classified by Flores \& Espejel (1994) as coastal dunes vegetation. According to these authors, this type of vegetation extends along the entire coast of the Peninsula and is only interrupted by strip mangroves and lime cliffs located at specific points on the coastline. In general, it grows on sandy soils and, on the coast of Quintana Roo; it may be adjacent to rocky areas where pioneer herbaceous and creeping species, as well as other shrubs are developed (Flores \& Espejel 1994).
The coastal dunes vegetation is subdivided into two main types (Espejel 1984, Chan et al. 2002, Torres et al. 2010), according to the zone where it is located along a stabilization gradient (Jiménez-Orocio et al. 2015). The first type consists of species of the pioneer zone and is located on the coastline adjacent to the sea on the embryonic dunes and to the windward side of the first dune cord. This group is composed of annual herbs, shrubs and halophytes from one to two meters high. The second type consists of the coastal scrub zone species, located on the windward face of the first dune, and from that point to the boundary with the mangrove or tropical forest (Durán et al. 2010). This group is composed of shrub species and sometimes small trees, with or without spines, and variable heights that reach up to three meters (Chan et al. 2002).

In the Mexican Caribbean, the pioneer species that colonize the beach, the embryonic dunes (which represent the initial stages of sand dunes formation), and the first frontal cord of sand dunes are Sesuvium portulacastrum, T. gnaphalodes, C. uvifera, S. maritima y Euphorbia buxifolia; and the characteristic species of shrub strata in this region are Thrinax radiata, Coccothrinax readii, Bravaisia berlandieriana, Pithecellobium keyense, Cascabela gaumeri, Cordia sebestena, Sideroxylon americanum, B. macrocarpa, Erithalis fruticosa, Agave angustifolia, Leucaena leucocephala, $C$. uvifera, Metopium brownei, Bursera simaruba, Coccoloba barbadensis, Piscidia piscipula y Diospyros salicifolia (Moreno-Casasola et al. 2014).

For the Island of Cozumel, the third largest island of Mexico which is located in the Mexican Caribbean, Téllez et al. (1989) recognize the presence of coastal vegetation, which is classified for them as halophilous vegetation or coastal dunes vegetation. They describe their development in sandy and gravelly soils, and report the eight plant associations: (1) Ambrosia hispida - Opuntia stricta - I. pes-caprae; (2) Canavalia rosea - Tephrosia cinerea - Sophora tomentosa; (3) Thournefortia gnaphalodes - S. maritima - C. uvifera; (4) Thrinax radiata-Hymenocallis littoralis-I. pes-caprae; (5) Thrinax radiata - Caesalpinia bonduc; (6) Rachicallis americana - E. fruticosa-Ernodea littoralis; (7) Salicornia bigelovii-Batis maritima; (8) Vallesia antillana-Quadrella incana - Enriquebeltrania crenatifolia. Although, at the island level some research has been carried out to evaluate the general characteristics of the vegetation in coastal dunes (Téllez et al. 1989, Flores 1992), there is no plant community characterization of the North East of the island, particularly from the terrestrial vegetation of the coastal system. In order to address the following question: How are the structure and composition of well-preserved coastal vegetation communities in the island of Cozumel? This work describes the composition, structure and diversity (alpha and beta) of the vegetation of the rocky and sandy vegetal communities of the North East of Cozumel, Mexico.

\section{Materials and methods}

Study site. The island of Cozumel is located in the Caribbean Sea, off the coast of the Yucatan Peninsula, $17.5 \mathrm{~km}$ from the 
city of Playa del Carmen $\left(20^{\circ} 20^{\prime} 00^{\prime \prime}-20^{\circ} 30^{\prime} 00^{\prime \prime} \mathrm{N}\right.$ and $87^{\circ}$ $00^{\prime} 00^{\prime \prime}-86^{\circ} 50^{\prime} 00^{\prime \prime} \mathrm{W}$ ) (Figure 1). It is an oceanic island of approximately $490 \mathrm{~km}^{2}$ and has a humid warm Am (f) (i) climate, with summer rains, an average annual rainfall of 1570 $\mathrm{mm}$ and an average annual temperature of $25.5^{\circ} \mathrm{C}$ (García 1981). The predominant soil in the island are rendzina; they are shallow, and they have good structure and drainage. Geologically, the most accepted hypothesis about its geological origin is that the island was formed from a detachment of the eastern margin of the peninsula, when the basin of Yucatan was formed, between the Late Mesozoic and the Early Cenozoic (Uchupi 1973). Like the Yucatan Peninsula Plate, the island is constituted by sediments and calcareous rocks of marine origin from the Tertiary and recent Quaternary. The island of Cozumel is practically flat with shallow slopes, mainly flat in its western portion and steep in its northern and eastern coasts (INEGI 2002). According to the physiognomic-floristic criteria proposed by Miranda (1959), the most important vegetation types of the island of Cozumel are medium stature subdeciduous forest, low stature deciduous forest, mangroves, coastal dunes vegetation and palm grove (Téllez et al. 1989, Flores 1992).

The main economic activity on the Island is tourism, which has developed in the western coastal area of the island of Cozumel (Palafox-Muñoz \& Collantes-Chávez Costa 2008). Approximately $80 \%$ of the island of Cozumel is sheltered by different protected natural areas, one municipal, 2 state and 2 federal ones.
The Flora and Fauna Protection Area of Cozumel is located at the north east part of the island of Cozumel which was decreed on the 25 th of September 2012 and covers a total surface of 37,829 ha (DOF 2012). It is a federal protected area that has a coastal line of approximately $50 \mathrm{Km}$ long, from which a stripe of $25 \mathrm{~km}$ long by $150 \mathrm{~m}$ width corresponds to a coastal vegetation ecosystem. Vegetation of this strip is classified as coastal dunes vegetation, and different plant associations can be distinguished, all in good conserved condition (DOF 2012).

Floristic composition. For the evaluation of the coastal vegetation types of the Island of Cozumel Flora and Fauna Protection Area, fifteen canfield lines were carried out in the summer of 2014 (Canfield 1941, Matteucci \& Colma 1982, Brower et al. 1998). Five canfield lines of $80 \mathrm{~m}$ located perpendicular to the coastline were randomly established every $100 \mathrm{~m}$ from each other in three environments: rocky beaches, sandy beaches and coastal dunes. The species registered were identified on site at the species level by qualified personnel of the herbarium of the Centro de Investigación Cientifica de Yucatán (CICY) and Universidad de Quintana Roo (UQRoo), and the vouchers of plants collected were deposited at the herbarium of Plant Ecology Laboratory-UQRoo. For the taxonomic nomenclature of families, genera and species we followed the APG III (2009), and the scientific names and families were corroborated in The International Plant Names Index (IPNI 2012).

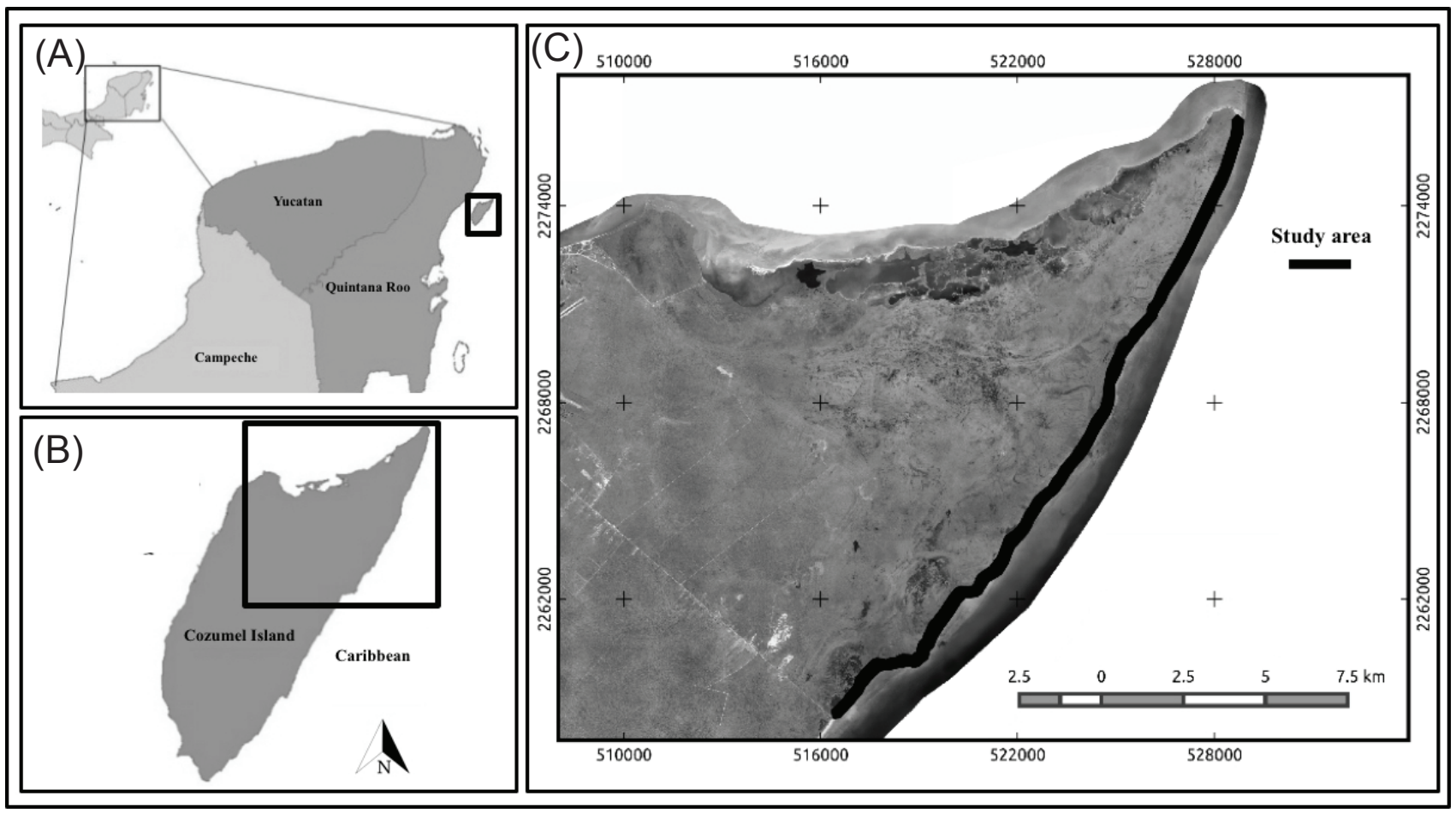

Figure 1. A. Location of the Yucatan Peninsula, Mexico. B. Island of Cozumel. C. The study area highlighted with dark line, located along the northeast area of the Flora and Fauna Protection Area of Cozumel Island (APFFIC). 
Community structure. In each of the canfield line, the coverage and frequency by species were determined, the coverage being the measure obtained from the perpendicular projection of the aerial structures of each plant to the line; and the frequency, the number of plant clumps or individual plants per specie presents along the line. In order to calculate the Importance Value Index (Brower et al. 1998), the plant community was characterized horizontally in terms of its relative density of the species, and its coverage and relative frequency. The first one (relative density of the species $i$, $R D_{i}$ ) was obtained by the formula:

$$
R D_{i}=\left(\frac{n_{i}}{\Sigma_{n}}\right) \times 100
$$

where $n_{i}$ is the total number of individuals of the species $i$ collected and $\Sigma n$ is the total number of individuals of all species. The relative coverage of the species $i\left(R C_{i}\right)$ was determined by:

$$
R C_{i}=\left(\frac{l_{i}}{\Sigma l}\right) \times 100
$$

where $l_{i}$ is the sum of the interceptions in the length for the species $i$ (total length of transects intercepted by the species $i)$ and $\Sigma l$ is the total of the interceptions in the length.

The relative frequency of the species $i\left(R F_{i}\right)$ was calculated by the following equation:

$$
\begin{gathered}
R F_{i}=\left(\frac{f_{i}}{\Sigma f}\right) \times 100 \\
f_{i}=j_{i} / k
\end{gathered}
$$

where $f_{i}$ is the frequency of the species $i, j_{i}$ is the number of interception lines in which the species $i$ is present, $k$ is the total number of interception lines. The Importance Value Index of the species $i\left(I V I_{i}\right)$ was calculated by:

$$
I V I_{i}=\frac{R D_{i}+R C_{i}+R F_{i}}{3}
$$

The Shannon index $\left(H^{\prime}\right)$ was used to determine alpha diversity, which is based in the community structure, that is, the proportional distribution of the value of each species (Moreno 2001). For its calculation the following equation was used:

$$
\begin{gathered}
H^{\prime}=-\sum_{i=1}^{S} p_{i} \times \ln \left(p_{i}\right) \\
p_{i}=n_{i} / N
\end{gathered}
$$

where $p_{i}=n / N$ and $\ln$ is the natural logarithm, $N$ is the total number of individuals and $n_{i}$ is the number of individuals of the species $i$.

After verifying the statistical assumptions of normality, homoscedasticity and independence among the observations, one factor (plant community) Analysis of Variance (ANO-
VA) was carried out at three levels determined by the type of environment (rocky beaches, sandy beaches and coastal dunes) between the ecological parameters of density and coverage and species richness and Shannon index $(P \leq 0,05)$. As a Post Hoc test the Tukey HSD test was used. The statistical program used was the SPSS version 22.0 (SPSS 1976).

Floristic similarity. To determine the similarity in the composition of the species among the sampling units, beta diversity was used. For this, the Bray-Curtis sorting analysis was developed (Bray \& Curtis 1957). The results are represented in a dendrogram, thereby determining the similaritydissimilarity between the sampling areas. The analysis was done using the BioDiversity Professional Version 2 computer package (McAleece et al. 1997).

\section{Results}

Floristic composition. Twenty-three families, 35 genera and 37 species were registered. (Table 1). The most representative families are Poaceae with four species, and Rubiaceae and Asteraceae with three species each; Sideroxylon and Euphorbia were the richest genera, with two species each. The rest of the families are represented by a number of 1 to 2 species. According to the life habit, 18 herbaceous, 12 arboreal (treelets), 6 shrubby, and 1 palm species were recorded.

Community structure. The species density did not vary among environments. However, a marginal difference among them is reflected (d.f. $=14 ; F=3.717 ; P=0.055$ ). The density on the sandy beaches was greater than that observed on the rocky beaches, and that of the coastal dunes greater than the first; the vegetation established in sandy beaches was $42 \pm 10.70$ (median \pm SD) individuals per line, while rocky beaches presents $31 \pm 11.46$, and coastal dune $56.80 \pm 17.28$. The most representative species for the latter were $T$. radiata, Ambrosia hispida, Euphorbia mesembryanthemifolia and I. pes-caprae (Relative Density, RD $=65.49 \%$ ). On the rocky beaches, $T$. gnaphalodes, C. uvifera, Conocarpus erectus and $R$. americana $(\mathrm{RD}=59.99 \%)$ mark a dominance over the other species. For the sandy beaches, the species $C$. rosea, E. mesembryanthemifolia and I. pes-caprae are the most dominant $(\mathrm{RD}=56.88 \%)($ Table 2$)$.

The relative coverage also did not vary among environments, but showed a marginal difference (d.f. $=14$; $F=3.832 ; P=0.052$ ); the plant community established on the rocky beaches presented a coverage of $43.65 \pm 7.43 \mathrm{~m}$, whereas in the coastal dunes vegetation was $72.67 \pm 16.88$ $\mathrm{m}$. The most representative species for Relative Coverage on Coastal dunes were $T$. radiata and $S$. americanum $(\mathrm{RC}=$ $61.72 \%$ ); for rocky beaches $C$. uvifera, C. erectus, $R$. americana, $S$. americanum, and T. gnaphalodes $(\mathrm{RC}=75.43 \%)$; and for sandy beaches A. hispida, C. rosea, I. pes-caprae ( $\mathrm{RC}=76.79 \%$ ).

The highest values for relative frequency in the coastal dunes correspond to T. radiata, A. hispida, Batis maritima, Chrysobalanus icaco, Distichlis spicata, E. mesembryanthemifolia and T. gnaphalodes that represent a $49.15 \%$ of the 
Table 1. Scientific and common name, family and life habit of the species registered in the study area.

\begin{tabular}{|c|c|c|c|}
\hline Scientific Name & Common Name & Family & Life habit \\
\hline Acanthocereus tetragonus (L.) Hummelinck & tsakam, nuum tsutsuy (maya). & Cactaceae & Herbaceous \\
\hline Ageratum maritimum Kunth & unknown & Asteraceae & Herbaceous \\
\hline Ambrosia hispida Pursh & $\begin{array}{l}\text { sea altanisa, sea daisy ; muuch' kook, k'an lool } \\
\text { xiiw (maya). }\end{array}$ & Asteraceae & Herbaceous \\
\hline Batis maritima $\mathrm{L}$. & $\begin{array}{l}\text { alambrillo, mañanita de la mar, wild parsley; } \\
\text { ts'aay kaan (maya). }\end{array}$ & Bataceae & Herbaceous \\
\hline Borrichia arborescens (L.) DC. & sea daisy; k'an lool xiiw (maya). & Asteraceae & Shrub \\
\hline Bursera simaruba (L.) Sarg. & mulatto stick; chakaj (maya). & Burseraceae & Tree \\
\hline Cakile lanceolata O.E. Schulz & unknown & Brassicaceae & Herbaceous \\
\hline Canavalia rosea (Sw.) DC. & frijolillo, sea bean & Fabaceae & Herbaceous \\
\hline Chrysobalanus icaco L. & icaco, nut & Chrysobalanaceae & Shrub or Tree \\
\hline Coccoloba uvifera $\mathrm{L}$. & sea grape, beach grape; ni' che' (maya). & Polygonaceae & Tree \\
\hline Conocarpus erectus L. & botoncillo & Combretaceae & Tree \\
\hline Cordia sebestena $\mathrm{L}$. & $\begin{array}{l}\text { anacahuite, siricote blanco, beach siricote; } \\
\text { k'oopte', sak k'oopte' (maya). }\end{array}$ & Boraginaceae & Tree \\
\hline Crotalaria pumila Ortega & garbancillo & Fabaceae & Herbaceous \\
\hline Dactyloctenium aegyptium (L.) Willd. & $\begin{array}{l}\text { crow's foot chimes su'uk, } \mathrm{k}^{\prime} \text { an toop su'uk } \\
\text { (maya). }\end{array}$ & Poaceae & Herbaceous \\
\hline Digitaria insularis (L.) Fedde & nej boob (maya). & Poaceae & Herbaceous \\
\hline Distichlis spicata (L.) Greene & baakel aak' (maya). & Poaceae & Herbaceous \\
\hline Ernodea littoralis $\mathrm{Sw}$. & unknown & Rubiaceae & Tree \\
\hline Euphorbia dioeca Kunth & xana mukuy (maya). & Euphorbiaceae & Herbaceous \\
\hline Euphorbia mesembryanthemifolia Jacq. & siis ja', sak iits (maya). & Euphorbiaceae & Herbaceous \\
\hline Gomphera sp. & & Amaranthaceae & Herbaceous \\
\hline Hymenocallis littoralis (Jacq.) Salisb. & unknown & Amaryllidaceae & Herbaceous \\
\hline Ipomoea pes-caprae (L.) R. Br. & beach rattan or riñonina & Convolvulaceae & Herbaceous \\
\hline Lantana involucrata $\mathrm{L}$. & $\begin{array}{l}\text { orégano xiiw (español -maya); sikil ja' xiiw } \\
\text { (maya). }\end{array}$ & Verbenaceae & Shrub \\
\hline Metopium brownei Urb. & cheechem, boox cheechem (maya). & Anacardiaceae & Tree \\
\hline Neea psychotrioides Donn.Sm. & ta'tsi' (maya). & Nyctaginaceae & Shrub or Tree \\
\hline Pithecellobium keyense Britton & ya'ax k'aax (maya). & Fabaceae & Shrub or Tree \\
\hline Rachicallis americana Hitchc. & unknown & Rubiaceae & Shrub \\
\hline Randia sp. & & Rubiaceae & Tree \\
\hline Scaevola plumieri Vahl & chunup (maya). & Goodeniaceae & Tree \\
\hline Sesuvium portulacastrum $\mathrm{L}$. & beach purslane; ts'a'aykann, xukul (maya). & Aizoaceae & Herbaceous \\
\hline Sideroxylon americanum (Mill.) T.D. Penn. & $\begin{array}{l}\text { caimitillo, real peak (Spanish); mulche', puuts' } \\
\text { mukuy, péech kitam, sak ts'iits'il che' (maya). }\end{array}$ & Sapotaceae & Tree \\
\hline Sideroxylon obtusifolium (Roem. \& Schult.) T.D. Penn. & $\begin{array}{l}\text { zapotillo (Spanish); baalche'kéej, ja'as tóoch, } \\
\text { pak' aal che', puuts' mukuy, káapoch (maya). }\end{array}$ & Sapotaceae & Tree \\
\hline Sporobolus virginicus (L.) Kunth & ch'ilibil su'uk (maya). & Poaceae & Herbaceous \\
\hline Suriana maritima $\mathrm{L}$. & pats'il (maya) & Surianaceae & Tree \\
\hline Thrinax radiata Lodd. ex Schult. \& Schult. f. & chit Palm, coast guano & Arecaceae & Palm \\
\hline Tournefortia gnaphalodes (L.) Roem. \& Schult. & tabaquillo; sik'imay (maya). & Boraginaceae & Tree \\
\hline Tribulus cistoides $\mathrm{L}$. & $\begin{array}{l}\text { thistle (Spanish); chan koj xnuk, chan xnuuk } \\
\text { (maya). }\end{array}$ & Zygophyllaceae & Herbaceous \\
\hline
\end{tabular}


Table 2. Relative density (RD), relative coverage (RC), relative frequency (RF) and index value importance (IVI) of the three plant communities studied.

\begin{tabular}{|c|c|c|c|c|c|c|c|c|c|c|c|c|}
\hline \multirow[b]{2}{*}{ Species } & \multicolumn{4}{|c|}{ Coastal dune } & \multicolumn{4}{|c|}{ Rocky beach } & \multicolumn{4}{|c|}{ Sandy beach } \\
\hline & $\begin{array}{l}\text { RD } \\
(\%)\end{array}$ & $\begin{array}{l}\text { RC } \\
(\%)\end{array}$ & $\begin{array}{l}\text { RF } \\
(\%)\end{array}$ & $\begin{array}{l}\text { IVI } \\
(\%)\end{array}$ & $\begin{array}{l}\text { RD } \\
(\%)\end{array}$ & $\begin{array}{l}\mathrm{RC} \\
(\%)\end{array}$ & $\begin{array}{l}\text { RF } \\
(\%)\end{array}$ & $\begin{array}{l}\text { IVI } \\
\text { (\%) }\end{array}$ & $\begin{array}{l}\text { RD } \\
\text { (\%) }\end{array}$ & $\begin{array}{l}\mathrm{RC} \\
(\%)\end{array}$ & $\begin{array}{l}\text { RF } \\
(\%)\end{array}$ & $\begin{array}{l}\text { IVI } \\
(\%)\end{array}$ \\
\hline Acanthocereus tetragonus & 1.06 & 0.63 & 1.69 & 1.13 & 0 & 0 & 0 & 0 & 0 & 0 & 0 & 0 \\
\hline Ageratum maritimum & 0 & 0 & 0 & 0 & 6.45 & 1.29 & 10.87 & 6.2 & 0 & 0 & 0 & 0 \\
\hline Ambrosia hispida & 14.44 & 8.23 & 6.78 & 9.82 & 0 & 0 & 0 & 0 & 11.37 & 25.5 & 30.77 & 22.55 \\
\hline Batis maritima & 2.82 & 2.31 & 6.78 & 3.97 & 0.65 & 0.09 & 2.17 & 0.97 & 1.9 & 0.55 & 0 & 0.82 \\
\hline Borrichia arborescens & 0 & 0 & 0 & 0 & 1.94 & 0.74 & 4.35 & 2.34 & 0 & 0 & 0 & 0 \\
\hline Bursera simaruba & 0 & 0 & 0 & 0 & 1.29 & 2.15 & 2.17 & 1.87 & 0 & 0 & 0 & 0 \\
\hline Cakile lanceolata & 0.35 & 0.04 & 1.69 & 0.7 & 1.29 & 0.23 & 2.17 & 1.23 & 0 & 0 & 0 & 0 \\
\hline Canavalia rosea & 2.82 & 0.86 & 1.69 & 1.79 & 0 & 0 & 0 & 0 & 15.17 & 22.09 & 0 & 12.42 \\
\hline Chrysobalanus icaco & 4.23 & 6.08 & 6.78 & 5.7 & 0 & 0 & 0 & 0 & 0 & 0 & 0 & 0 \\
\hline Coccoloba uvifera & 1.41 & 1.1 & 5.08 & 2.53 & 14.84 & 30.03 & 10.87 & 18.58 & 0.47 & 0.07 & 7.69 & 2.75 \\
\hline Conocarpus erectus & 0 & 0 & 0 & 0 & 14.19 & 20.29 & 10.87 & 15.12 & 0 & 0 & 0 & 0 \\
\hline Cordia sebestena & 1.41 & 1.97 & 3.39 & 2.26 & 1.94 & 1.28 & 2.17 & 1.8 & 0 & 0 & 0 & 0 \\
\hline Crotalaria pumila & 0.35 & 0.28 & 1.69 & 0.77 & 0 & 0 & 0 & 0 & 0 & 0 & 0 & 0 \\
\hline Dactyloctenium aegyptium & 0.35 & 0.11 & 1.69 & 0.72 & 0 & 0 & 0 & 0 & 0 & 0 & 0 & 0 \\
\hline Digitaria insularis & 1.06 & 1.22 & 3.39 & 1.89 & 0 & 0 & 0 & 0 & 10.9 & 9.52 & 0 & 6.81 \\
\hline Distichlis spicata & 5.28 & 0.92 & 6.78 & 4.33 & 3.23 & 0.4 & 4.35 & 2.66 & 7.11 & 2.24 & 0 & 3.12 \\
\hline Ernodea littoralis & 0.7 & 0.8 & 3.39 & 1.63 & 0 & 0 & 0 & 0 & 0.47 & 0.18 & 7.69 & 2.78 \\
\hline Euphorbia chamaesyce & 0 & 0 & 0 & 0 & 2.58 & 2.55 & 2.17 & 2.43 & 0 & 0 & 0 & 0 \\
\hline Euphorbia mesembryanthemifolia & 9.15 & 5.03 & 6.78 & 6.99 & 8.39 & 1.39 & 10.87 & 6.88 & 15.17 & 4.48 & 0 & 6.55 \\
\hline Gomphrena sp. & 0 & 0 & 0 & 0 & 0 & 0 & 0 & 0 & 3.79 & 0.52 & 0 & 1.44 \\
\hline Hymenocallis littoralis & 1.41 & 1.27 & 5.08 & 2.59 & 0 & 0 & 0 & 0 & 0 & 0 & 0 & 0 \\
\hline Ipomoea pes-caprae & 9.15 & 2.2 & 5.08 & 5.48 & 0 & 0 & 0 & 0 & 26.54 & 29.2 & 0 & 18.58 \\
\hline Lantana involucrata & 0.35 & 0.08 & 1.69 & 0.71 & 0 & 0 & 0 & 0 & 0 & 0 & 0 & 0 \\
\hline Metopium brownei & 0 & 0 & 0 & 0 & 0.65 & 4.9 & 2.17 & 2.57 & 0 & 0 & 0 & 0 \\
\hline Neea psychotrioides & 0.7 & 0.5 & 1.69 & 0.96 & 0 & 0 & 0 & 0 & 0 & 0 & 0 & 0 \\
\hline Pithecellobium keyense & 0.35 & 0.08 & 1.69 & 0.71 & 0 & 0 & 0 & 0 & 0 & 0 & 0 & 0 \\
\hline Rachicallis americana & 0 & 0 & 0 & 0 & 14.19 & 7.76 & 8.7 & 10.22 & 0 & 0 & 0 & 0 \\
\hline Randia sp. & 0.7 & 0.19 & 1.69 & 0.86 & 0 & 0 & 0 & 0 & 0 & 0 & 0 & 0 \\
\hline Scaevola plumieri & 0 & 0 & 0 & 0 & 0 & 0 & 0 & 0 & 0.47 & 2.4 & 7.69 & 3.52 \\
\hline Sesuvium portulacastrum & 0.35 & 0.11 & 1.69 & 0.72 & 0 & 0 & 0 & 0 & 0 & 0 & 0 & 0 \\
\hline Sideroxylon americanum & 4.93 & 9.67 & 1.69 & 5.43 & 3.87 & 8.52 & 2.17 & 4.86 & 0 & 0 & 0 & 0 \\
\hline Sideroxylon obtusifolium & 0 & 0 & 0 & 0 & 1.29 & 3.62 & 2.17 & 2.36 & 0 & 0 & 0 & 0 \\
\hline Sporobolus virginicus & 0.35 & 0.12 & 1.69 & 0.72 & 1.29 & 0.21 & 2.17 & 1.22 & 0 & 0 & 0 & 0 \\
\hline Suriana maritima & 0.35 & 0.43 & 1.69 & 0.83 & 3.23 & 3.57 & 4.35 & 3.71 & 0 & 0 & 0 & 0 \\
\hline Thrinax radiata & 32.75 & 52.05 & 8.47 & 31.09 & 1.94 & 2.13 & 4.35 & 2.8 & 0 & 0 & 0 & 0 \\
\hline Tournefortia gnaphalodes & 2.11 & 3.25 & 6.78 & 4.05 & 16.77 & 8.83 & 10.87 & 12.16 & 1.9 & 2.33 & 30.77 & 11.67 \\
\hline Tribulus cistoides & 1.06 & 0.45 & 3.39 & 1.63 & 0 & 0 & 0 & 0 & 4.74 & 0.92 & 15.38 & 7.01 \\
\hline Total & 100 & 100 & 100 & 100 & 100 & 100 & 100 & 100 & 100 & 100 & 100 & 100 \\
\hline
\end{tabular}


total, all off them with the same value except for $T$. radiata. For the rocky beaches, Ageratum maritimum, $C$. uvifera, $C$. erectus, E. mesembryanthemifolia and $T$. gnaphalodes show the same higher relative frequency values, adding the $54.35 \%$ of the total. As for the sandy beaches A. hispida and $T$. gnaphalodes represent the $61.54 \%$ of the total relative frequency (Table 2).

Besides, the three plant communities showed statistical similarity in the Shannon diversity index (d.f. $=14 ; F=$ 1.929; $P=0.188$ ) (Figure 2). The plant community established on the rocky beaches presented a value of $1.97 \pm$ 0.21 , while the one established on the sandy beaches was $1.54 \pm 0.64$, and the established in coastal dunes $1.98 \pm 0.19$ (Figure 2).

The plant community established in the coastal dunes presented higher species richness per intercept line than that developed sandy beaches community (d.f. $=14 ; F=6.288$; $P=0.014$ ), with $12.40 \pm 1.67$ and $7.40 \pm 3.04$ respectively (Figure 2). The rocky beaches community presented statistical equality with the other two communities, with $9.20 \pm 1.78$ species per interception line (Figure 2).

Floristic similarity. Similarity dendrogram using Bray-Curtis similarities, highlighting the difference in plant composition between the rocky beach environment, and the coastal dune and sandy beach environments. According to the Bray-Curtis similarity dendrogram, these two large groups show a similarity of $29.07 \%$ (Figure 3). The first group consists of the five transects established on the rocky beaches, which had a similarity of $45.5 \%$; the representative species of this group are $C$. erectus, $R$. americana, B. arborescens and S. obtusifolium. The second cluster groups transects established in the coastal dunes and sandy beaches, and shows a similarity of $37.03 \%$ (Figure 3), being A. hispida, C. rosea, D. insularis, E. littoralis, I. pes-caprae, and T. cistoides the main shared species.

\section{Discussion}

In our study, the species richness of the rocky beaches community $(9.20 \pm 1.78)$ is similar than that observed in other works carried out in similar communities. González et al. (2015) identify a total of 7 species in the a similar phytosenosis called rocky coast complex, characterized by the presence of $R$. americana and $C$. erectus (on the coast of Cuba). On the other hand, for the same study, González et al. (2015) recognize a total of 126 species for sandy coast vegetation, while for our work we find 28 species. This difference could be due to the non-sampling method used by these authors.

The difference between the observed richness from the coastal dunes vegetation contrasted to the sandy beaches vegetation is mainly due to the fact that the former presents a gradient of substrate stability, organic matter content, and salinity conditions, which confers a greater variability of environments that can harbor a greater variety of species. Species representative of the environment were Acanthocereus tetragonus, $H$. littoralis, Lantana involucrata, Neea psychotrioides, Pithecellobium keyense, Sesuvium portulacastrum, and $T$. radiata. In addition, it had several species of sandy beaches vegetation, in embryonic coastal dunes, which
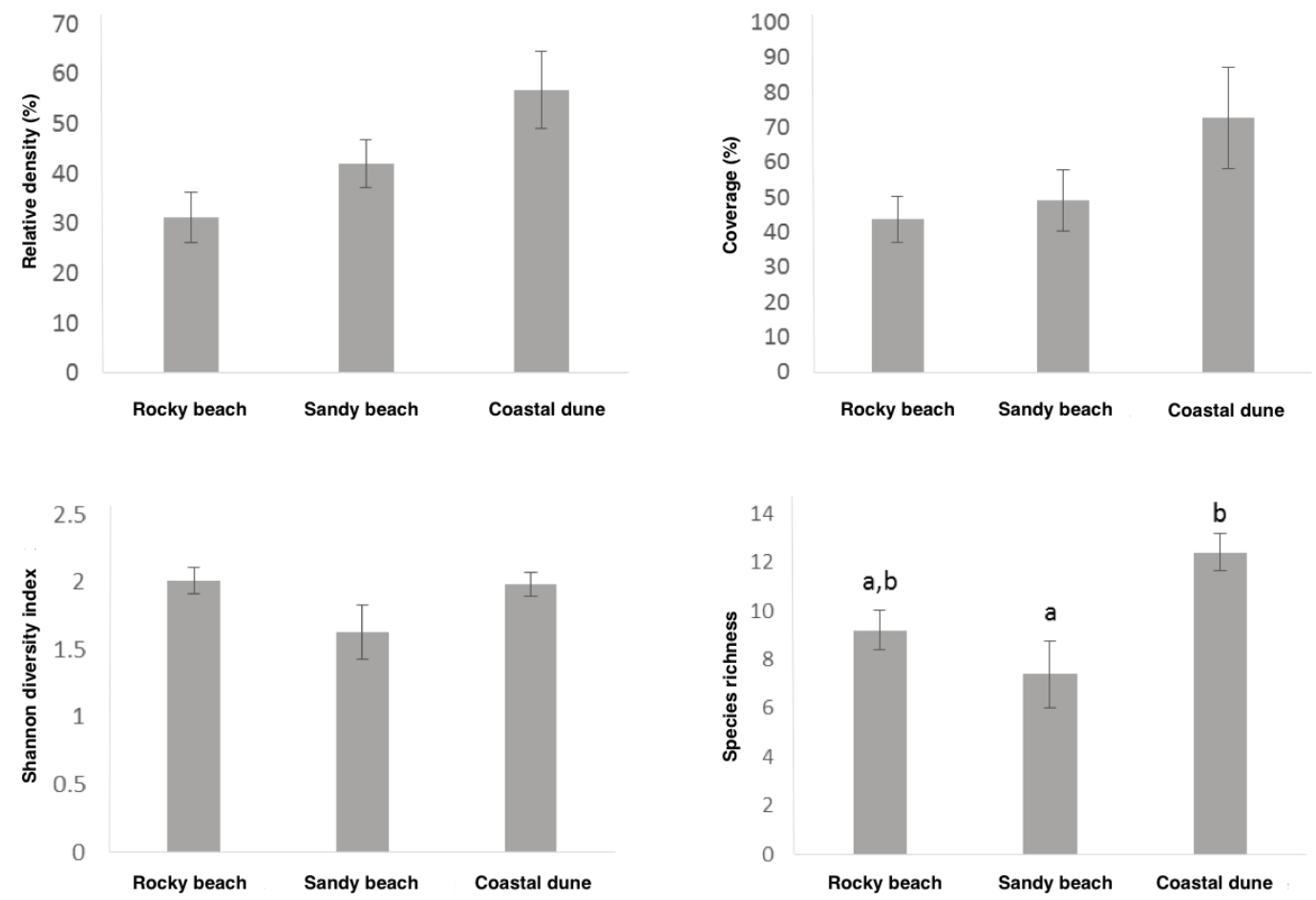

Figure 2. Means \pm typical errors of the variables of relative density, coverage, Shannon index $\left(H^{\prime}\right)$ and species richness (S). 


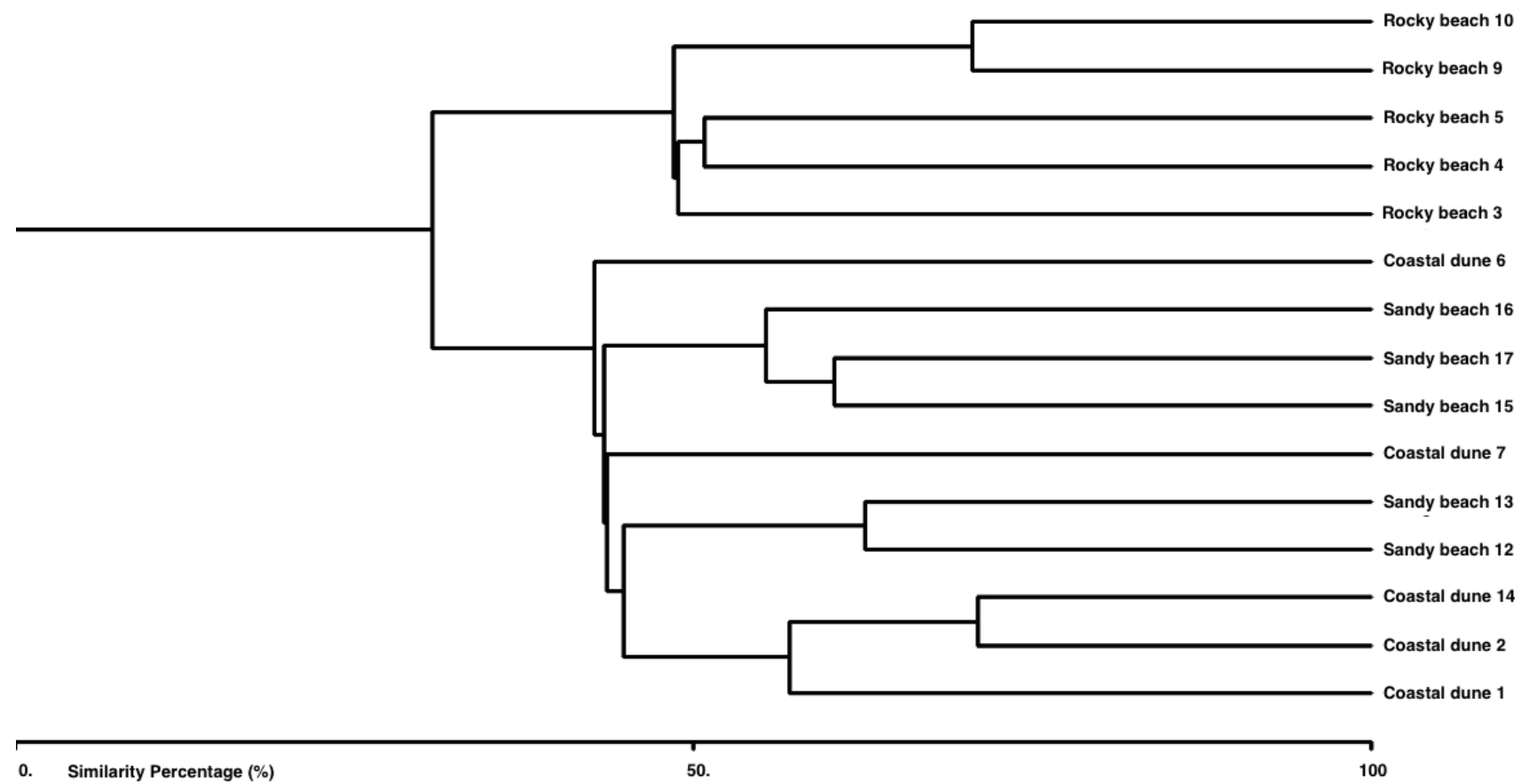

Figure 3. Bray-Curtis Dendrogram for the floristic similarity of 15 sampled sites.

are the area located between the littoral zone and windward side of the coastal dunes (e.g., A. hispida, C. rosea and I. pes-caprae).

The vegetation coverage in the three environments is similar to that observed by Torres et al. (2010) for the coastal shrub of the Yucatan Peninsula, which ranges between 41 and 85 . These results could be related to the general environmental conditions presented in the coastal line that limit the coverage of the characteristic vegetation (Etherington1975). Likewise, for Caribbean coastal communities, Reys \& Acosta-Cantillo (2003) describe in Cuba similar coverages to those observed in the study herein; particularly for rocky beaches they observe coverages between 5 and $25 \%$ of $C$. erectus, less than $5 \%$ of $R$. americana, coverage related to the scattered availability of substrate. $C$. erectus, $R$. americana and $B$. arborescens have different morphological and physiological adaptations that allow them to establish themselves, and grow in conditions of moderate to high salinity, caused by the splashing of seawater and occasional flooding of the scattered karst cavities of the rocky environments. There, strong winds, high insolation and temperature, and sudden changes in humidity and drought occur. All these are characteristic of the supra-tidal movement and the climatic conditions of these environments (Brunt 2012). In general, these species have a life habit of decumbent, prostrate and occasionally erect, but always of low height. The $R$. americana and B. arborescens species are Nanofanerophytes species, with leptophilic and microphilic leaves respectively (Martínez-Quezada 2014), to deal with strong winds and high insolation. C. erectus has two salt glands at the base of the leaves and tolerates salinity conditions of up to 120 UPS (Agraz-Hernández et al. 2006).
The existing floristic similarity between the plant communities of sandy beaches and coastal dunes can be explained by the presence of A. hispida, E. mesembryanthemifolia, $C$. rosea and $I$. pes-caprae, species shared between sandy beaches and embryonic coastal dunes. These plants are pioneer species that are established in areas where sand has not been stabilized (Espejel 1984, Chan et al. 2002, Torres et al. 2010, Jiménez-Orocio et al. 2015). They are stress tolerant, low height, and produce abundant seeds. It has herbaceous habit, lateral growth (mostly postrate or decumbent), and roots adapted to the mobility of the substrate. A. hispida, also produces abundant low sized seeds, that are dispersed by the wind, attributes that could explain its relative high IVI in these environments. C. rosea and I. pes-caprae further have a well-developed vegetative reproduction, and produce seed that can float in salt water, allowing them a wide distribution and colonization capacity of beaches and coastal dunes (Devall 1992 and Mendoza-González et al. 2014 ).

Sandy beaches also presented scattered individuals of $T$. gnaphalodes and C. uvifera (Figures $4 \mathrm{a}$ and b), which are species characteristic of coastal dunes vegetation (Rzedowski 2006) (Figures $5 \mathrm{a}$ and b). These two species also occur in the area opposite to the shore of the rocky beaches, in the inner limit of the rocky beaches, where the subtrate is abundant and stable (Figures 6 a and b). T. gnaphalodes and C. uvifera, in adition to Distichlis spicata, and E. mesembryanthemifolia, explain the $29 \%$ of the similarity between the vegetation of rocky beaches, and the group formed by the sandy beaches and coastal dunes vegetation. In this area, the substrate is sandy-grainy, and it is where $T$. gnaphalodes and C. uvifera can be established (Parrotta 1994). 


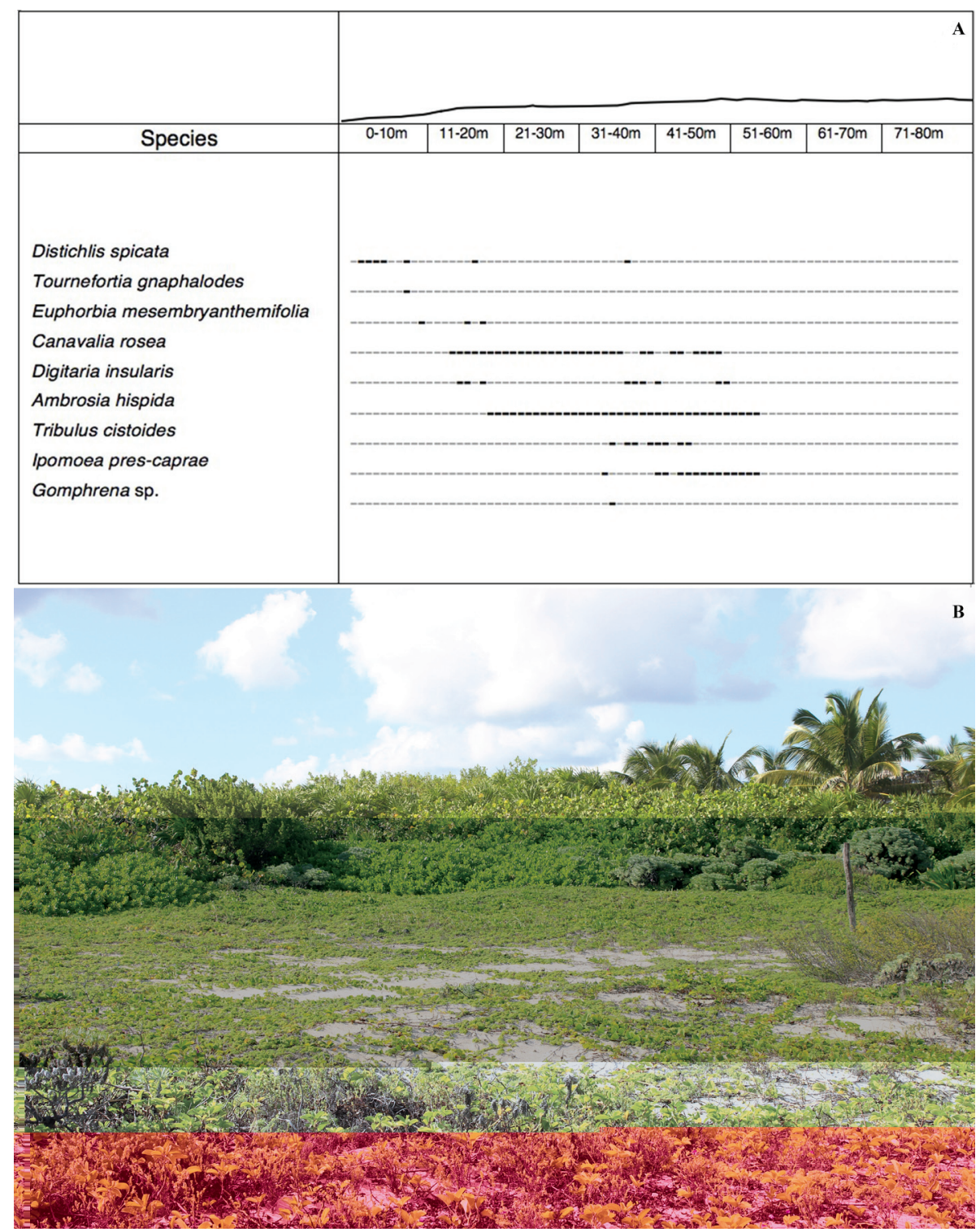

Figure 4. A. Vegetation profile of a typical sandy beaches association of the northeast coastal area of the Island of Cozumel, Quintana Roo. The intervals are in metric units; the cero meter corresponds to the tide line. The points in bold font represent the location of the species and their coverage. B. Typical sandy beaches association of the northeast coastal area of the Island of Cozumel, Quintana Roo.

The difference between the floristic composition of the rocky beaches in relation to the group formed by the other two communities, is mainly determined by $C$. erectus and $R$. americana, that can be established in harsh environments, with little substrate present in small hollows of the rock, and subject to the conditions of high salinity caused by exposure to the sea breeze and splashing waves (Brunt 1994). This result suggests the presence of two different plants association into the halophilous vegetation, that present differences in terms of the substrate (sandy and rocky).

The rocky beaches vegetal community described in our research has some floristic and phytosociological similarities with Cayman Islands, Jamaica, and Swan Islands (Proctor
1994, Brunt 1994). For the rocky beaches, the characteristic association found corresponds to that formed by Borrichia arborescens, $R$. americana and $C$. erectus, dominant species of phytocenosis, and consistently reported in the CaribbeanMesoamerican biogeographic region (Rivas-Martínez 1997), both in Cayman Islands (Sauer 1983, Brunt 1994), and Cuba (Reys \& Acosta-Cantillo 2003, Martínez-Quesada 2014). It is particularly recognized in the biogeographic Cuban and Yucatanian / Lesser Antillean Provinces, and it is a phytocenosis that is classified as follows:

Class: Sesuvio-Rachicallietea Borhidi (Borhidi et al. 1979, Borhidi et al. 1983) 

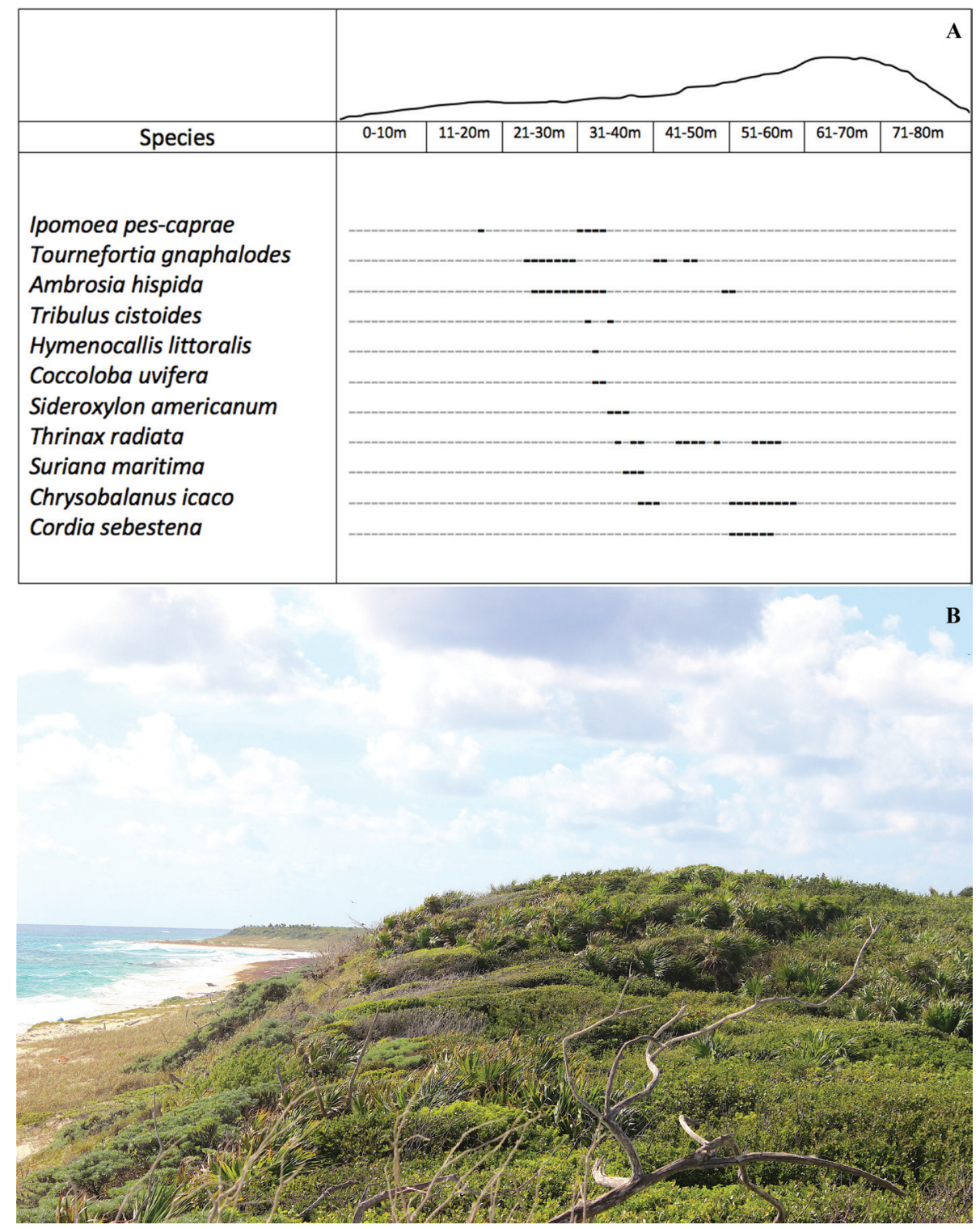

Figure 5. A. Vegetation profile of a typical coastal dunes association of the northeast coastal area of the Island of Cozumel, Quintana Roo. The intervals are in metric units; the cero meter corresponds to the tide line. The points in bold font represent the location of the species and their coverage. The height of the dune is on a scale proportional to the coverage intervals. B. Typical coastal dunes association of the northeast coastal area of the Island of Cozumel, Quintana Roo.

Order: Borrichio-Rachicallietalia Borhidi (Borhidi et al. 1979, Borhidi et al. 1983)

Alliance: Rachicalli-Borrichion (Samek 1973)

Association: Borrichio-Rachicalletum americanae (Reys \& Acosta-Cantillo 2003, Samek 1973).

Finally, while it is strongly suggested that the relationships between the biota of the Yucatan Peninsula were closer to the Centroamenican ones than to the ones of the center of Mexico or from the Antilles (Estrada-Loera 1991, Ibarra-Manríquez et al. 2002, Carnevali et al. 2003, and Ramírez-Barahona et al. 2009), the presence of the species $R$. americana (whose records are restricted to some sites the coast of Quintana Roo and Cozumel), and the Borrichio-Rachicalletum americanae phytocenosis (present on the rocky beaches), not only show the biogeographical relation of the island of Cozumel with the Caribbean zone from the shared taxa, but also in their plant associations and Caribbean landscape, so that the protection of this coastal systems of the Cozumel Island contributes to the conservation of Mexico's biodiversity.

\section{Acknowledgements}

The present study was carried out with funds from the Con- 

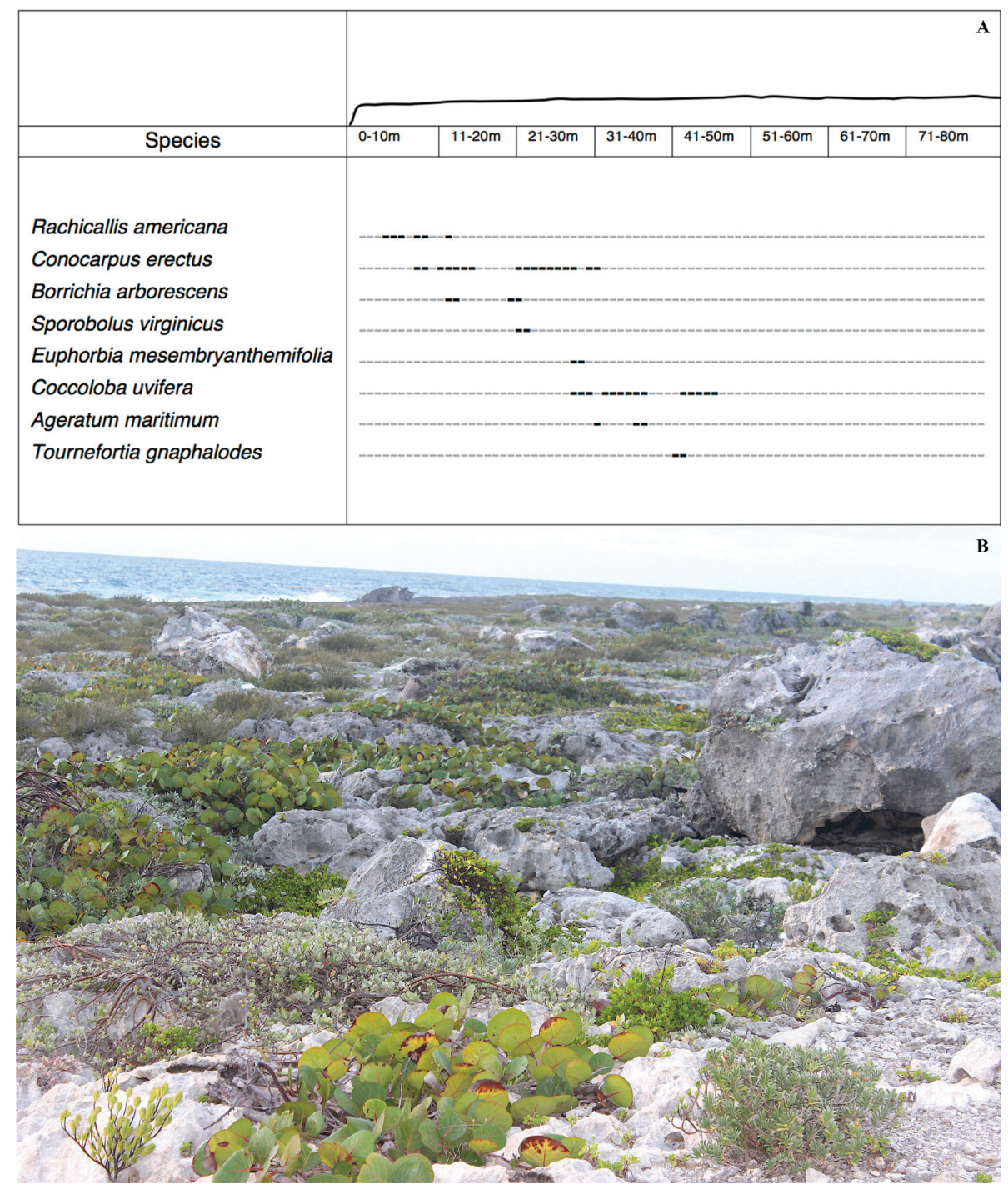

Figure 6. A. Vegetation profile of a typical rocky beaches association in the northeast coastal area of the Island of Cozumel, Quintana Roo. The intervals are in metric units; the cero meter corresponds to the tide line. Points in bold font represent the location of the species and their coverage. B. Typical rocky beaches association of the northeast coastal area of the Island of Cozumel, Quintana Roo.

servation of Species at Risk Program (Programa de Conservación de Especies en Riesgo) granted by the National Commission of Natural Protected Areas (Comisión Nacional de Áreas Naturales Protegidas) to the project "9.1 Characterization of the coastal dune beach system of the Island of Cozumel". We would like to thank to Laura Scott-Morales, Roberto Velázquez Tagle and the anonymous reviewers who helped us with their observations to improve this manuscript.

\section{Literature cited}

Acevedo-Rodríguez P, Strong MT. 2008. Floristic richness and affinities in the West Indies. The Botanical Review 74: 5-36. DOI: https://doi.org/10.1007/s12229-008-9000-1
Agraz-Hernández C, Noriega-Trejo R, López-Portillo J, FloresVerdugo F, Jiménez-Zacarías J. 2006. Guía de campo. Identificación de los manglares en México. Universidad Autónoma de Campeche. ISBN: 9685722455

APG III. 2009. An update of the Angiosperm Phylogeny Group classification for the orders and families of flowering plants: APG III. Botanical Journal of the Linnean Society 161:10512. DOI: https://doi.org/10.1111/j.1095-8339.2009.00996.x

Borhidi A, Muniz O, Del Risco E. 1979. Clasificacion fitocenológica de la vegetation de Cuba. Acta Botanica Academiae Scientiarum Hungaricae 25: 263-301.

Borhidi A, Muniz O, Del Risco E.1983. Plant communities of Cuba, I. Fresh and salt water, swamp and coastal vegetation. Acta Botanica Hungarica 29: 337-376.

Bray JR, Curtis JT. 1957. An ordination of the upland forest 
communities of southern Wisconsin. Ecological monographs 27: 325-349. DOI: https://doi.org/10.2307/1942268

Brower JE, Zar JH, von Ende C. 1998. Field and laboratory methods for general ecology. USA: McGraw-Hill. ISBN-13: 978-0697243584

Brunt M. 1994. Phytogeography of the Cayman Island. In: Brunt MA, Davies JE, eds. The Cayman Islands: Natural History and Biogeography. Springer Science Bussiness Media, 245282. DOI: https://doi.org/10.1007/978-94-011-0904-8 eBook ISBN 978-94-011-0904-8

Canfield RH. 1941. Application of the line interception method in sampling range vegetation. Journal of forestry 39: 388 394. DOI: https://doi.org/10.1093/jof/39.4.388

Carboni M, Carranza ML, Acosta A. 2009. Assessing conservation status on coastal dunes: a multiscale approach. Landscape and urban planning 91:17-25.

DOI: https://doi.org/10.1016/j.landurbplan.2008.11.004.

Carnevali G, Ramírez-Morillo I, González Iturbe JA. 2003. Flora y vegetación de la Península de Yucatán. In: Colunga GarcíaMarín P, Larqué-Saavedra A, eds. Naturaleza y Sociedad del Área Maya: pasado, presente y futuro. Mérida, Yucatán: Centro de Investigación Científica de Yucatán, A.C. 53-68. ISBN: 9687428198

Chan C, Rico-Gray V, Flores JS. 2002. Guía ilustrada de la flora costera representativa de la Península de Yucatán. Etnoflora Yucatanense 19:1-94.

Devall M. 1992. The biological flora of coastal dunes and wetlands. 2. Ipomoea pes-caprae (L.) Roth. Journal of Coastal Research. 442-456.

DOF [Diario Oficial de la Federación]. 2012. Decreto por el que se declara área natural protegida, con el carácter de Área de protección de flora y fauna, la porción norte y la franja costera oriental, terrestres y marinas de la Isla de Cozumel. $<$ http://www.dof.gob.mx/nota_detalle.php?codigo $=5270007$ $\&$ fecha $=25 / 09 / 2012>$ (accessed January 4, 2018).

Durán R, Torres W, Espejel I. 2010. Vegetación de dunas costeras. In: Durán R, Méndez M, eds. Biodiversidad y desarrollo humano en Yucatán, CICY. Conabio. Mérida, Seduma, 136137. ISBN: 978-607-7823-08-7

Espejel I. 1984. La vegetación de las dunas costeras de la península de Yucatán. I. Análisis florístico del estado de Yucatán. Biótica 9:183-210.

Estrada-Loera E. 1991. Phytogeographic relationships of the Yucatan Peninsula. Journal of Biogeography 18: 687-697. DOI: https://doi.org/10.2307/2845550

Etherington JR. 1975. Environment and plant ecology. John Wiley \& Sons Ltd. ISBN-13: 978-0471246152

Flores JS. 1992. Vegetación de las islas de la península de Yucatán: florística y etnobotánica. Etnoflora Yucatanense 4: 1-71.

Flores JS, Espejel I. 1994. Tipos de vegetación de la Península de Yucatán. Etnoflora Yucatanense 3: 1-35.

García E. 1981. Modificaciones al sistema de clasificación climática de Köppen. Para adaptarlo a las condiciones de la República Mexicana. México D.F.: Instituto de Geografía, Universidad Nacional Autónoma de México.

González PA, Gómez, JL, Leyva O, Hernández Y. 2015. Flora de la Reserva Florística Manejada Cabo Lucrecia-Punta de
Mulas, Banes, Holguín. Revista Jardín Botánico Nacional 36: $65-77$.

Herrera-Silveira JA, Comín FA, Capurro FL. 2005. Los Usos y Abusos de La Zona Costera en la Península de Yucatán. In: Rivera-Arriaga E, Villalobos-Zapata GJ, Azuz-Adeath I, Rosado-May F, eds. El manejo costero en México. Universidad Autónoma de Campeche, SEMARNAT, CETYS- Universidad de Quintana Roo, 387-396. ISBN 968-5722-12-9

Ibarra-Manríquez G, Villaseñor JL, Durán R, Meave J. 2002. Biogeographical analysis of the tree flora of the Yucatan Peninsula. Journal of Biogeography 29: 1729. DOI: https://doi.org/10.1046/j.1365-2699.2002.00648.x

INEGI. 2002. Estudio Hidrológico del estado de Quintana Roo. Gobierno del Estado de Quintana Roo, México.

Isla FI. 2013. From touristic villages to coastal cities: The costs of the big step in Buenos Aires. Ocean \& coastal management 77: 59-65.

DOI: https://doi.org/10.1016/j.ocecoaman.2012.02.005.

IPNI. 2012. The International Plant Names Index. $<$ https://www. ipni.org> (accessed July 17, 2018).

Jiménez-Orocio O, Espejel I, Martínez ML. 2015. La investigación científica sobre dunas costeras de México: origen, evolución y retos. Revista mexicana de biodiversidad $\mathbf{8 6}$ : 486-507. DOI: https://doi.org/10.1016/j.rmb.2015.04.022.

Martínez ML, Moreno-Casasola P. 1993. Survival of seedling cohorts of a tropical legume on a sand dune system along the Gulf of Mexico: influence of germination date. Canadian Journal of Botany 71: 1427-1433. DOI: https://doi.org/10.1139/b93-172.

Martínez-Quesada E. 2014. Nuevos sintáxones del archipiélago de los Jardines de la Reina, Cuba. Acta Botanica Malacitana 39: 99-115.

Matteucci SD, Colma A. 1982. Metodología para el estudio de la vegetación. Washington, DC.: Secretaría General de la Organización de los Estados Americanos.

McAleece N, Lambshead PJ, Paterson GL, Cage JD. 1997. Biodiversity Professional (V.2.0). Natural History Museum and Scottish Association for Marine Science.

Mendoza-González G, Martínez M, Lithgow D. 2014. Biological flora of coastal dunes and wetlands: Canavalia rosea (Sw.) DC. Journal of Coastal Research 30: 697-713. DOI: https://doi.org/10.2112/JCOASTRES-D-13-00106.1

Miller TE, Gornish ES, Buckley HL. 2010. Climate and coastal dune vegetation: disturbance, recovery, and succession. Plant ecology 206: 97-104.

DOI: https://doi.org/10.1007/s11258-009-9626-z

Miranda F. 1959. La vegetación de la península Yucateca. In: Beltrán E. Los recursos naturales del sureste y su aprovechamiento. México: Instituto Mexicano de Recursos Naturales Renovables. 215-271.

Miranda FD, Hernández E. 1963. Los tipos de vegetación de México y su clasificación. Boletín de la Sociedad Botánica de México: 28: 29-179.

DOI: https://doi.org/10.17129/botsci.1084

Moreno C. 2001. Métodos para medir la biodiversidad. Zaragoza, España: Programa Iberoamericano de Ciencia y Tecnología para el Desarrollo. ORCYT; Oficina Regional de Ciencia y Tecnología para América Latina y el Caribe. 
UNESCO. Sociedad Entomológica Aragonesa (SEA). ISBN: 84-922495-2-8

Moreno-Casasola P. 2004. Las playas y dunas del Golfo de México. Una visión de la situación actual. In: Caso M, Pisanty I, Escurra E, eds. Diagnóstico ambiental del golfo de México. México DF.: SEMARNAT, 491-520. ISBN: 9688177059

Moreno-Casasola P, Espejel, I, Castillo S, Castillo G, Durán R. 1998. La flora costera de México. In: Halffter G, ed. La Biodiversidad Biológica de Iberoamerica II. Instituto de Ecología, 177-260. ISBN 968-7863-33-1

Moreno-Casasola P, Espejel I, Jiménez-Orocio O, Infante-Mata D, Rodríguez-Revelo N. 2014. Flora y vegetación. In: Martínez ML, Moreno-Casasola P, Espejel I, Jiménez-Orocio O, Infante-Mata D, eds. Diagnóstico general de las dunas costeras de México. México. D.F.: Comisión Nacional Forestal, 27-48.

Palafox-Muñoz A. Collantes-Chávez Costa A. 2009. El turismo en ambientes sensibles. Caso Isla de Cozumel, México. Análisis del Turismo, 4: 49-63.

Parrotta A. 1994. Coccoloba uvifera (L.) L. Sea grape. Uva de playa. Polygonaceae. Buckwheat. Buckwheat family. USDA Forest Service. International Institute of Tropical Forestry.

Proctor GR. 1994. Phytogeography of the Cayman Island. In: Brunt MA, Davies JE, eds. The Cayman islands: Natural History and Biogeography. Springer Science Bussiness Media, 237-244. eBook ISBN: 978-94-011-0904-8, DOI: https://doi.org/10.1007/978-94-011-0904-8

Ramírez-Barahona S, Torres-Miranda A, Palacios-Rios M, Luna-Vega I. 2009. Historical biogeography of the Yucatan Peninsula, Mexico: a perspective from ferns (Monilophyta) and lycopods (Lycophyta). Biological Journal of the Linnean Society 98: 775-786.

DOI: https://doi.org/10.1111/j.1095-8312.2009.01331.x
Reys OJ, Acosta-Cantillo F. 2003. Fitocenosis presentes en las áreas costeras del sur de la Sierra Maestra, Cuba. I. Comunidades con influencia marina. Foresta Veracruzana 5: 1-7.

Rivas-Martínez SR. 1997. Syntaxonomical synopsis of the potential natural plant communities of North America. 1. Itinera geobotánica 10: 5-148.

Rzedowski J. 2006. Vegetación de México. México: Comisión Nacional para el Conocimiento y Uso de la Biodiversidad.

Samek V. 1973. Pinares de la sierra de Nipe; Estudio sinecológico. Academia de Ciencias de Cuba, Serie Forestal 14: $1-158$.

Sauer JD. 1983. Cayman Islands seashore vegetation: a study in comparative biogeography. Univ. of California Press. ISBN13: 978-0520096561

Seingier G, Espejel I, Almada JL. 2009. Cobertura vegetal y marginación en la costa mexicana. Investigación ambiental Ciencia y política pública 1: 54-69.

SPSS. 1976. Statistical Package for the social sciences. Chicago, IL, USA.

Téllez O, Cabrera E, Linares E, Bye R. 1989. Las Plantas de Cozumel. México D.F.: Instituto de Biología, UNAM.

Torres W, Méndez M, Dorantes A, Durán R. 2010. Estructura, composición y diversidad del matorral de duna costera en el litoral yucateco. Boletín de la Sociedad Botánica de México 86: 37-51. DOI: http://dx.doi.org/10.17129/botsci.1830

Uchupi E. 1973. Eastern Yucatan continental margin and Western Caribbean Tectonics. American Association of Petroleum Geologists Bulletin 57:1075-1085.

Wolfe SA, Nickling WG. 1993. The protective role of sparse vegetation in wind erosion. Progress in physical geography 17: $50-68$.

DOI: https://doi.org/10.1177/030913339301700104.

Associated editor: Ivón Ramírez-Morillo.

Author Contributions: ACC conceived the project, designed the field method, conducted the field work and part of the analyses, wrote part of the paper, and prepared the paper. EAR participated in the field work, conducted part of the analyses, and wrote part of the paper. OYU participated in the field work and prepared the paper. CLC participated in the field work, and in the taxonomic identification, and prepared the paper. TSM participated in the field work and prepared the paper. JLTM conducted the taxonomic identification and prepared the paper. 